\title{
Dr William Hunter (1718-83) and the gravid uterus
}

\author{
Peter M Dunn
}

William, the seventh child of John and Agnes Hunter, was born at Long Calderwood, Kilbride, Lanarkshire, 23 May 1718. At the age of 14 he entered the University of Glasgow to study theology, but after five years decided to become a doctor and for three happy years assisted Dr William Cullen in Hamilton. In 1741, after a brief period of study in Edinburgh, he travelled to London to become first a house pupil of the famous Dr William Smellie and then assistant to the distinguished obstetrician-anatomist, Dr James Douglas. $\mathrm{He}$ also studied surgery at St George's, London.

In 1747 Hunter was admitted to the Corporation of Surgeons and in 1750 received the degree of MD from the University of Glasgow; the Licentiate of the College of Physicians followed in 1756. In 1748 he was appointed to the Lying-in Department of the Middlesex Hospital and to the British Lying-in Hospital in 1749. Meantime his private practice was flourishing. By 1762, at the age of 44, when he was appointed Physician Extraordinary to Queen Charlotte, he had become the leading physicianman midwife of his day. ${ }^{12}$

From his earliest days in London, anatomy was Hunter's main interest. He wrote: "Anatomy is the only solid foundation of medicine; it is to the physician and surgeon what geometry is to the astronomer. It discovers and ascertains the truth, overturns superstition and vulgar error ..." He started his own course of lectures in 1746 and these continued till his death 37 years later. His young brother John, who was to become equally famous as a surgeon-scientist, joined him for 10 years as an assistant in 1748 . From 1751 William based his practice and anatomical work at 42 Jermyn Street, but in 1768 he opened a School for Anatomy in Great Windmill Street, with its own amphitheatre, dissecting rooms, and museum. It inaugurated a new era of anatomical study in England and its influence was worldwide.

William's special interest was the anatomy of the human gravid uterus, a field that had been largely ignored up to that time. In 1774 he published his great work on this subject. ${ }^{3}$ It was dedicated to King George III. In the preface he wrote: “... in the year 1751 the author met with the first favourable opportunity of examining the human species, what before he had been studying in brutes. A woman died suddenly, when very near the end of her pregnancy; the body was procured before any insensible putrefaction had begun; the season of the year

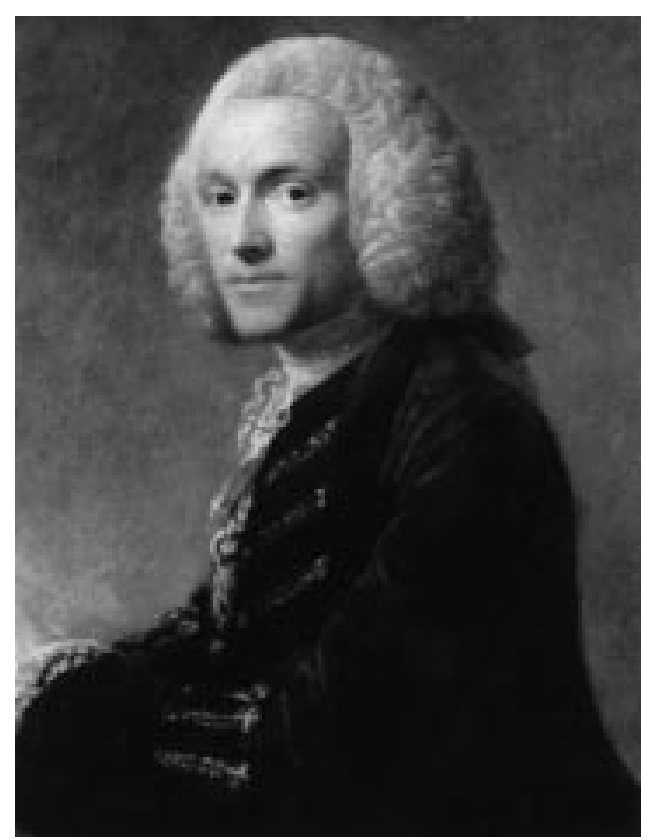

Figure 1 Dr William Hunter (17188-3). Painting by Allan Ramsay in the Hunterian Art Gallery, University of Glasgow.

was favourable to dissection; the injection of blood vessels proved successful; a very able painter, in this way, was found; every part was examined in the most public manner, and the truth well authenticated ..."

This great work, with its exquisite etched prints by Jan van Rymsdyk, was followed by a second, ${ }^{4}$ edited by his nephew Matthew Baillie and published 11 years after his death. These texts broke new ground in many ways. For example, he described the musculature of the uterus, including the contraction ring, and showed that the decidua was a lining of the uterus and not derived from the ovum. Another first was his description of the spiral arteries of the uterus, and he also noted that the uterine veins were without valves. Above all, with the aid of wax injections he was able to confirm that contrary to received wisdom at that time, the feto-placental circulation was completedly independent of that of the mother.

\section{On the independent feto-placental} circulation $^{4}$

"From all my experiments and observations, which have been often repeated and diligently attended to, with no other desire than to 
discover the truth, it seems incontestible that the human placenta is composed of two distinct parts, though blended together, viz., a foetal-umbilical, and a uterine which belongs to the mother - that each of those two parts has its own peculiar system of arteries and veins. But the circulation in these two parts differs in the following manner; in the umbilical portion the arteries terminate in the veins by a continuity of canal, whereas in the uterine portion there are intermediate cells into which the arteries terminate and from which the veins begin. Any injection of wax thrown into the uterine vessels fails to find its way into any of the umbilical vessels, and in the same manner wax injected into the umbilical vessel can never be pushed into the uterine, except by rupture or transudation. By many trials I know that plain water, or any simple fluid fit for transudation, thrown into the umbilical arteries or veins, readily gets into the cellular cavities of the placenta and thence into the veins of the uterus. The umbilical portion of the placenta is of a simple nature, a regular ramification of the arteries and veins without any lateral anastomosis, so that when unravelled it has the appearance of a tree whose branches divide to almost infinite minuteness towards its outer surface and through its substance."

Hunter also described the feto-placental circulation in some detail, including the ductus venosus, foremen ovale, and ductus arteriosus. He wrote: “ ... the child is entirely nourished by the navel string....For my part I think this is all done by absorption, and the navel string and its branches are like the roots of a child which are bathed in the blood and juices of the mother, which they absorb and take up and carry to the child ..."

William had written in the preface to his text $^{3}$ : "In most of (my) dissections (I) was assisted by my brother Mr John Hunter, whose accuracy in anatomical researches is so well known, that to omit this opportunity of thanking him for his assistance, would be in some measure to disregard the future reputation of the work itself." However, this was not enough for John, who claimed the discovery of the fetal circulation for himself. A quarrel ensued that was only resolved on William's deathbed. This dispute was all the more unfortunate in that William Harvey had already made the same observation more than 120 years earlier.

Hunter also published several original papers and at least 15 manuscripts of his lectures have survived, though none of his authorship. In these management of labour, the care of the mother during the puerperium, children's diseases, and even the choice of a wet nurse are discussed. His observations debunked many of the old wives' tales of his time, such as the belief that the fetus tumbled into the vertex position late in pregnancy and that it delivered itself by its own efforts. He had great faith in the natural physiology of childbirth: "I have as great a deference to what is natural before what is artificial" and "In most cases (in managing labour) though, I pretend to be doing something yet I do very little for them, and hardly anything more than to take off the reproach of my doing nothing at all." $\mathrm{He}$ added: "There are two things at the time of labour which I am frightened at (all the others I do not care a sixpence for), one is the flooding and the other convulsions." Hunter had no liking for the forceps of which he wrote: " ... where they save one they murder twenty." $\mathrm{He}$ studied the symphysis pubis in pregnancy and strongly opposed the use of symphysectomy. With regard to the third stage of labour he wrote: "The hurrying away the placenta is just as bad as hurrying on the labour, and forcing away the placenta is a terrible practice ... Nature does work much better for the mother and child than art, therefore no force should be used ... I know this to be an improvement of infinite consequence ..." Yet another of his original observations concerned the management of the retroverted gravid uterus.

Hunter was of small stature, scholarly, and had a courtly and engaging manner (fig 1). $\mathrm{He}$ was cheerful, unassuming, and inspired confidence and esteem. His perception and judgment were excellent and he was very attentive to his patients. He lived simply and was immensely industrious. In 1742 he had become betrothed to James Douglas's daughter, Martha Jane who died two years later. He remained a batchelor, wedded to his work.

Among his friends he numbered Hogarth, Reynolds, Gainsborough and Samuel Johnson. Many honours and appointments came his way: Fellow of the Royal Society (1767) and Society of Antiquities (1768); Professor of Anatomy to the Royal Academy (1768); President of the Medical Society of London (1780); Foreign Associate of the Royal Medical Society of Paris (1780) and of the Royal Academy of Sciences of Paris (1783).

For the last 10 years of his life, Hunter's health began to fail. But he continued to work as hard as ever. During a lecture in March 1783 he collapsed with a stroke, and died a few days later. On his deathbed he is reported to have said: "If I had the strength to hold a pen, I would write how easy and pleasant a thing it is to die." $\mathrm{He}$ was buried in the rector's vault of St James's Church, Piccadilly. His anatomical specimens, his library, and many collections of minerals, coins, shells and other objects of natural history were left in the keeping of his nephew Dr Baillie, to be handed on in 1808 to the University of Glasgow. Dr Baillie wrote of Hunter, that "no one ever possessed more enthusiam for his art, more persevering industry, more acuteness of investigation, more perspicuity of expression, or, indeed, a greater share of natural eloquence. He excelled very much any lecturer whom I have ever heard in the clearness of his arrangement, the aptness of his illustrations, and the elegance of his diction. He was perhaps the best teacher of anatomy that ever lived."

1 Andrews HR. William Hunter and his work in midwifery. $B M \mathcal{F} 1915 ; \mathbf{i}: 277-82$.

2 Illingworth Charles. The story of William Hunter. Edinburgh: Churchill Livingstone, 1967

3 Hunter W. The anatomy of the gravid uterus. Birmingham: Baskerville, 1774

4 Hunter W. An anatomical description of the human gravid uterus and its contents. Baillie M, ed. London: Johnson, 1794. 